\title{
Research on Modern University Chinese Teaching Design Based on Task Driven Teaching Method
}

\author{
FanXiaoyan \\ Nanchang Institute of Science \&Technology,Nanchang 330108,China
}

Keywords: College Chinese, Instructional design, Task driven, Target optimization, Adaptive, Particle swarm optimization.

\begin{abstract}
Through the analysis of the existing problems in College Chinese teaching design, this paper discusses the connotation and characteristics of the task driving teaching method. Based on the learning theory and constructivism learning theory, this paper proposes a modern Chinese teaching method based on task driven, and designs the adaptive model of teaching target and driving task, at the same time the use of particle swarm algorithm optimizes the driving task, which effectively improve the teaching effect of college Chinese. In order to verify the teaching effect of the task driven teaching method, this method carries out a term teaching experiment. Finally, based on the experimental data and the questionnaire survey, this paper analyzes the effect of task driving teaching method. The results show that college Chinese teaching method based on task driven can not only improve students' academic performance, but also can improve the students' learning ability and comprehensive quality.
\end{abstract}

\section{Introduction}

In the new teaching reform, many universities carry out the university Chinese teaching, which only pay attention to the infusion of the theoretical knowledge, so that students passive receive new theory and knowledge, and they can not get the skills of mastering knowledge [1-3]. With the implementation of new teaching reform, many schools begin to explore new methods of Chinese teaching, in which the task driven teaching method makes students from passive acceptance of knowledge into active acquisition of knowledge, to promote the students in the language application ability, autonomous learning ability and collaborative learning ability and other comprehensive quality development, in accordance with the modern language teaching personnel training objectives $[4,5]$. As a new teaching method, task driven teaching method is being accepted and advocated by the teachers, it is hoped that this study can provide a reliable reference method for the application of practice teaching.

\section{The Basic Features of University Chinese Task Driven Teaching Method}

According to the requirements of the new teaching reform, the task driving method of college Chinese teaching has obvious interactive features; the characteristics of the task driven teaching method is the main clue of the task, which plays the leading role of teachers; the students become the main body of Chinese learning, the three is the interactive teaching mode, and the structural frame is shown in Figure 1. 


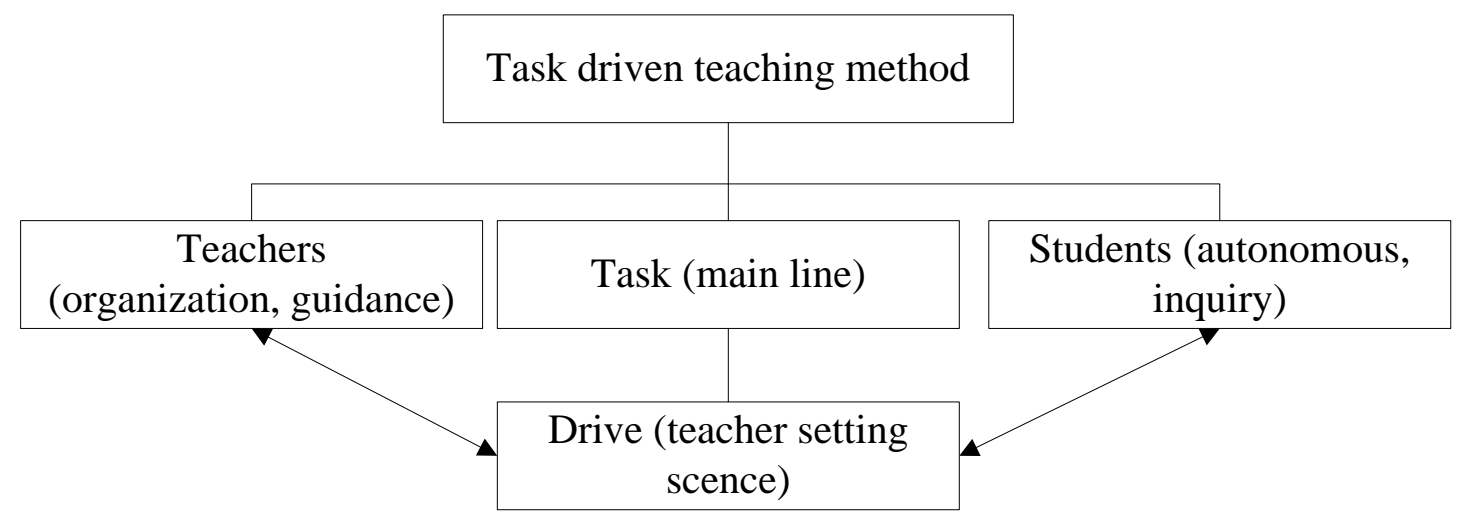

Fig.1 The basic framework of college Chinese task driving teaching method

Figure 1 represents the basic framework of college Chinese teaching method based on task driving, in which the teachers are responsible for organizing the task and guide the students to complete the task, and then teachers create situational language teaching, making the language learning becomes more lively; students play leading role and explore the Chinese task, to carry out independent inquiry and independent thinking. Through the group cooperation, students can increase team cooperation spirit. Task driven teaching method has always been the main line, and the implementations of task driven teaching methods need to pay attention to the following issues [6-8]:

To determine the core of language teaching tasks. In the implementation of the language task driven teaching method, first of all we need to confirm the core content of the task. In teaching, we should take the task driven as the main body, the task goes throughout the whole teaching activity as the main line of teaching, and teachers arrange teaching content according to the driving task.

The leading role of teachers. In the task driven college Chinese teaching, teachers should pay attention to their dominant position, and are not a simple preaching, tuition and FAQ; according to the teaching objectives and teaching content, teachers set targeted the tasks, and organize and guide the students to complete the task. After the completion of the task, teachers should actively create a learning atmosphere, so that students have to complete the task, improving students' ability of self-exploration. At the same time, teachers timely adjustment to the task and constantly encourage students, so that students can complete the teaching tasks efficiently.

The main body status of students. Task driven teaching method is an effective method for college Chinese teaching. In the task design, it takes into account the effect of teaching, and also takes into account the individual differences, so that each student can benefit from the completion of the task, to play a substantive effect of the task driven teaching method $[9,10]$.

(1) Making the students have a strong desire for knowledge. In the process of the task teaching method, teachers should focus on teaching students' learning ability and embody the teaching content of constructivism. At the same time, teachers set up the driving task, so that students have enough study interest, and teachers carry out a certain reward after students complete the task, to stimulate students' interest completing the next task.

(2) To improve students' ability of solving problems. Through the task driven teaching method, it can not only improve the students' learning interest, and the advantages of using task driven can quickly improve the students' ability of solving problems, so that students can solve problems in language teaching.

(3) Improving students' teamwork spirit. In the completion of language learning task, students need to communicate with the teacher and students and close cooperation, so that students and teachers have a wide range of communication, and students can improve the spirit of teamwork.

(4) Improving students' ability of independent learning. The college Chinese teaching method based on the driving task can help to form the students' knowledge transfer ability. Students will have a strong sense of honor when they complete the stage test, so that students can have a greater learning interest and enthusiasm, so as to improve their learning efficiency and academic performance. 


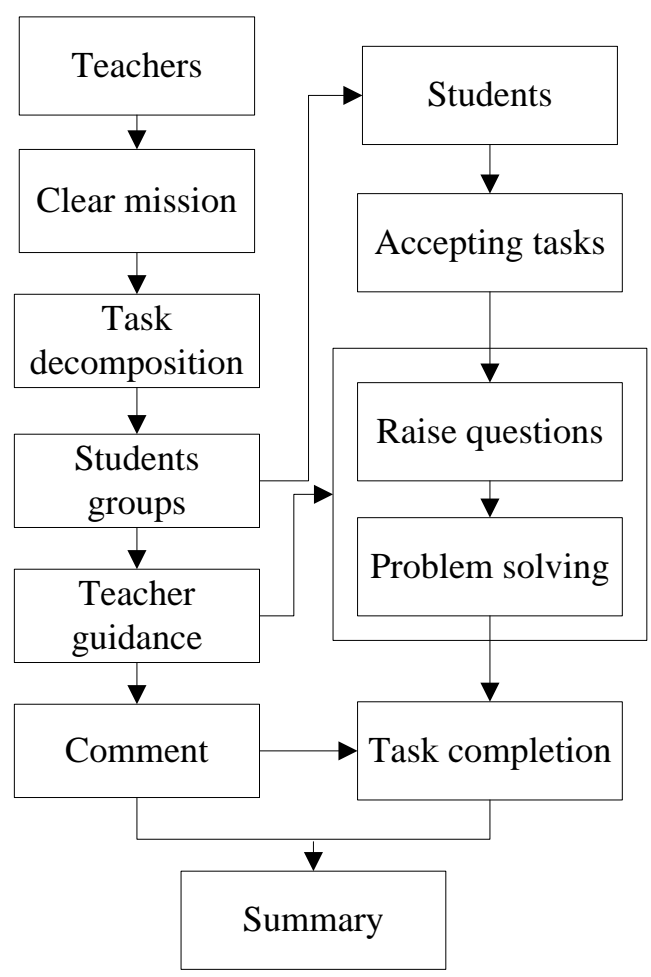

Fig.2 The specific implementation process of the task driven teaching method

Figure 2 shows the specific implementation process of the task driven teaching method. In order to achieve the task driven, the teachers first confirm the learning task according to students' individual differences, in which the task is decomposed into small tasks; finally, different students through the task carry out group, and students accept the task in accordance with group. Teachers guide the task, to help students to ask problems and solve the problem, the final completion of the task, and finally to summarize the task, to achieve the task of college Chinese teaching method.

\section{The Relevance Analysis of Chinese Teaching Objectives and Driving Task}

College Chinese teaching goal and driving task have a strong correlation. According to the optimization of the teaching objectives, the use of adaptive optimization method can set up a reasonable driving task. In a $D$-dimensional task space, there is a particle swarm composed by $N$ task in $D$ dimensional task space, in which the $i-t h$ task as a dimension vector can be written as:

$$
X_{i}=\left(x_{i 1}, x_{i 2}, \mathrm{~L}, x_{i D}\right), i=1,2, \mathrm{~L}, N \text {. }
$$

The goal of the $i-t h$ task is

$$
V_{\mathrm{i}}=\left(v_{i 1}, v_{i 2}, \mathrm{~L}, v_{i D}\right), i=1,2, \mathrm{~L} 3 .
$$

Through the task space search, the optimal value of the $i-t h$ task is obtained as the individual extreme value, which is

$$
p_{\text {best }}=\left(p_{i 1}, p_{i 2}, \mathrm{~L}, p_{i D}\right), i=1,2, \mathrm{~L}, N \text {. }
$$

The optimization task of the whole task space is the global extremum, and it is

$$
g_{\text {best }}=\left(p_{\text {best } 1}, p_{\text {best } 2}, \mathrm{~L}, p_{\text {best } D}\right) \text {. }
$$

Using the adaptive function carries out the fractal operation, and the fractal dimension is $F$, the formula is 


$$
d(F)=\lim _{\varepsilon \rightarrow 0} \frac{\ln N(\varepsilon)}{\ln (1 / \varepsilon)} .
$$

Where $N(\varepsilon)$ represents the number of the $F$ dimension tasks in the fractal dimension, and considering the complex function is

$$
Z_{n+1}=Z_{n}^{2}+F, \quad n=0,1, L \quad .
$$

Then, you can get the complex variable function iterative formula.

$$
Z=X+i V, \quad c=p+i g .
$$

Through the above formula, this paper can calculate the relevance between task and teaching objectives, so as to develop the driving task and modern Chinese teaching design.

\section{University Chinese Teaching Design and Experiment Research Based on Driving Task}

In order to test the effect of the task driven teaching method, this paper sets up the experimental classes and control classes to carry out the teaching experiment respectively, in which the experimental classes use the task driven method, and control classes use the traditional teaching method [11,12]. After a phase of teaching, the use of the same test method tests the effect of teaching,

\begin{tabular}{|c|c|c|c|c|c|c|c|}
\hline $\begin{array}{c}\text { Serial } \\
\text { number }\end{array}$ & $\begin{array}{c}\text { Test } \\
\text { content }\end{array}$ & Class & No. & $\begin{array}{l}\text { Mean } \\
\text { score }\end{array}$ & $\begin{array}{l}\text { Standard } \\
\text { deviation }\end{array}$ & $\mathrm{Z}$ value & Significant \\
\hline \multirow{2}{*}{1} & \multirow{2}{*}{ Grammar } & $\begin{array}{c}\text { Experimental } \\
\text { classes }\end{array}$ & 40 & 78.2 & 11.3 & \multirow{2}{*}{$0.9<1.2$} & \multirow{2}{*}{ Yes } \\
\hline & & $\begin{array}{c}\text { Control } \\
\text { classes }\end{array}$ & 40 & 76.3 & 12.5 & & \\
\hline \multirow{2}{*}{2} & \multirow{2}{*}{ Words } & $\begin{array}{c}\text { Experimental } \\
\text { classes }\end{array}$ & 41 & 79.3 & 10.8 & \multirow{2}{*}{$3.2>1.8$} & \multirow{2}{*}{ Yes } \\
\hline & & $\begin{array}{c}\text { Control } \\
\text { classes }\end{array}$ & 41 & 62.8 & 13.2 & & \\
\hline \multirow{2}{*}{3} & \multirow{2}{*}{ Sentence } & $\begin{array}{c}\text { Experimental } \\
\text { classes }\end{array}$ & 40 & 82.5 & 11.6 & \multirow{2}{*}{$2.3>1.85$} & \multirow{2}{*}{ Yes } \\
\hline & & $\begin{array}{l}\text { Control } \\
\text { classes }\end{array}$ & 40 & 72.1 & 15.2 & & \\
\hline
\end{tabular}
and the test results are obtained as shown in Table 1.

Table 1. The test results of task driven teaching method

As can be seen in Table 1, in the implementation of the task driven teaching method, student achievements have been significantly improved in various teaching links. The following two aspects of the teaching process is more obvious than the control class, due to the use of task driven method is more efficient than learning efficiency to improve students' learning ability.

Table 2. The survey of curriculum learning ability

\begin{tabular}{|c|c|c|c|c|c|}
\hline $\begin{array}{c}\text { Serial } \\
\text { number }\end{array}$ & \multirow{2}{*}{ Learning content } & Class & $\begin{array}{c}\text { Option A } \\
(\%)\end{array}$ & $\begin{array}{c}\text { Option B } \\
(\%)\end{array}$ & $\begin{array}{c}\text { Option C } \\
(\%)\end{array}$ \\
\hline \multirow{2}{*}{1} & Unit knowledge & Experimental classes & 91.2 & 5.2 & 3.6 \\
\cline { 3 - 6 } & summary & Control classes & 40 & 76.3 & 12.5 \\
\hline \multirow{2}{*}{2} & New knowledge & Experimental classes & 92.1 & 3.9 & 4.0 \\
\cline { 3 - 6 } & Preview & Control classes & 41 & 62.8 & 13.2 \\
\hline \multirow{2}{*}{3} & Class independent & Experimental classes & 40 & 82.5 & 11.6 \\
\cline { 3 - 6 } & control time & Control classes & 40 & 72.1 & 15.2 \\
\hline
\end{tabular}


Table 2 shows the survey results table of students' learning ability, in which the election of $A$ is very good, $B$ is good, and $C$ is not good. The results as shown in Table 2 can be seen that after the experimental classes implement the task driven teaching method, the learning ability and effect are higher than the control classes, in which more than $90 \%$ students can undertake unit summary through the knowledge learning, and they can be reasonable to preview the new knowledge after class, but also can also be a reasonable time to carry out autonomous thinking in class; when learning difficulties, students is not to avoid, but to actively think, this shows that college Chinese teaching method based on task driven has a very good teaching effect.

\section{Summary}

This paper analyzes the problems existing in the design of college Chinese teaching, and puts forward a kind of modern Chinese teaching method based on task driven. Using the particle swarm algorithm establishes the target optimization model and optimizes the driving task, and the optimal driving tasks are obtained. In order to verify the teaching effect of the task driven teaching method, the experimental class and the control class were set up, and they respectively carried out the teaching experiment, in which the experimental class uses the task driven teaching method, and the control class uses the traditional teaching method; through a semester's teaching, the teaching effect is tested. The test results showed that students significantly improved the achievements of grammar, vocabulary, sentence and various teaching links, and the following two teaching links was more obvious than control group, at the same time the driving task method could effectively improve the students' comprehensive learning ability, so it can be popularized in college Chinese teaching.

\section{References}

[1] G.F. Zhang. On the teaching mode of working task driving method. Education and occupation, 2013(4): 80-81.

[2] W. Yu. The task-based teaching is an effective way to achieve the new curriculum goal teaching. Technology Wenhui, 2013(2): 126-127.

[3]J. Gao. The internal motivation of German enterprises to participate in vocational education. Foreign primary and middle school education, 2014, 3(8): 16-18.

[4] J. Zhou, Z.J. Zhao. The present situation and thinking about the construction of modern education technology in public class. China education technology equipment, 2014, 5(2): 22-23.

[5] X.F. Liu. The current situation of the construction of modern education technology public course. Journal of Guangzhou Open University, 2013, 2(4): 46-51.

[6] B. Huang, S.R. Xu, W. Pu. Design and implementation of data mining platform based on MapReduce. Computer engineering and design, 2013, 34(2): 495-501.

[7] Q.S. Yu. The design and implementation of the logical regression model construction algorithm based on cloud platform. Technology Bulletin, 2013, 29(6): 137-139.

[8] Z.M. Gu, J.X. Zhang, C. Zheng. Overview of cloud computing research progress. Computer applications, 2013, 27(2): 429-433.

[9] Y. Yang. The advantages and disadvantages of multimedia teaching in English teaching. Journal of Jilin radio and TV University, 2013, 4(6): 146-147.

[10] M. Liu. The enlightenment of the modern educational technology in Singapore. Chinese audio visual education, 2013, 4 (11): 102-103.

[11] J.X. Lv. A preliminary study on the mixed learning theory in college English teaching. Journal of Changchun University of Science and Technology, 2013(7): 639-640. 